\title{
The Removal of Atrazine and Benalaxyl by the Fly Ash Released from Kosovo A Power Plant
}

\author{
Esad Behrami $\mathbb{D}^{1}{ }^{1}$ Kledi Xhaxhiu, ${ }^{1}$ Bedri Dragusha $\mathbb{D}^{2},{ }^{2}$ Arianit Reka, ${ }^{3}$ Adelaida Andoni, \\ Xhuljeta Hamiti, ${ }^{1}$ and Spiro Drushku' \\ ${ }^{1}$ Department of Chemistry, Faculty of Natural Sciences, University of Tirana, Tirana, Albania \\ ${ }^{2}$ Department of Pomology and Viticulture, Faculty of Agriculture and Veterinary, University of Prishtina, Pristina, Kosovo \\ ${ }^{3}$ Faculty of Natural Sciences and Mathematics, University of Tetovo, Ilinden n. n., 1200, Tetovo, North Macedonia \\ Correspondence should be addressed to Bedri Dragusha; bedri.dragusha@uni-pr.edu
}

Received 2 April 2021; Revised 23 November 2021; Accepted 26 November 2021; Published 27 January 2022

Academic Editor: Chanbasha Basheer

Copyright (C) 2022 Esad Behrami et al. This is an open access article distributed under the Creative Commons Attribution License, which permits unrestricted use, distribution, and reproduction in any medium, provided the original work is properly cited.

The development of low-cost adsorbent coal FA (Kosovo A) for pesticide removal is an important area of scientific research. With this study, we show the potential of adsorption of coal FA (Kosovo A) for the removal of benalaxyl and atrazine from water. We have found that the amount of adsorbed benalaxyl and atrazine increases with an increasing amount of coal FA (Kosovo A) in solution. The maximum capacity coal FA (Kosovo A) to adsorb benalaxyl and atrazine was found to be $0.46 \mathrm{and} 0.45 \mathrm{mg} / \mathrm{g}$ according to the Freundlich equation and 3.48 and $3.33 \mathrm{mg} / \mathrm{g}$ according to the Langmuir equation. The Freundlich adsorption equation better explains the adsorption results of pesticides (benalaxyl and atrazine) in coal FA (Kosovo A), as the values of the recovery coefficient $\left(R^{2}\right)$ were higher in Freundlich equation than the Langmuir equation. The adsorption isotherms were of type $\mathrm{L}$ and show that the adsorption efficiency of the coal FA (Kosovo A) depends on the initial concentration of benalaxyl and atrazine in solution and the maximum removal of benalaxyl and atrazine was achieved at concentrations less than $10 \mu \mathrm{g} / \mathrm{ml}$. This study's results are expected to have implications for the use of coal FA (Kosovo A) for the removal of pesticides from water.

\section{Introduction}

Fly ash (FA), a relatively abundant and inexpensive material, is currently being investigated as an adsorbent for the removal of various organic pollutants from wastewater [1]. Although all the pollutant treatment techniques can be employed, they have their inherent advantages and limitations. Among all these methods, adsorption process is considered better than other methods because of convenience, easy operation, and simplicity of design. A fundamentally important characteristic of good adsorbents is their high porosity and consequent larger surface area with more specific adsorption sites. This paper presents a review of adsorption of different pollutants using activated carbon prepared from FA sources and the attendant environmental implications. Also, the ways of overcoming barriers to fly FA utilization together with regeneration studies are also discussed. Regeneration is a very important aspect of the adsorption from economic and environmental point of view. It actually answers various questions and anxieties as to what would happen to the adsorbent after adsorption in order not to render the whole findings useless since such adsorbent may contain toxic adsorbates [2]. Fly ash is a type of industrial waste that can cause multiple environmental problems if discharged into the air. On the other hand, because of its high porosity, large specific surface area, and other unique characteristics, FA can also be used as a low-cost and high efficient adsorbent for the treatment of environment pollutants [3]. The utilization of FA from coal burning power plants to remove pollutants from aqueous solutions has also been studied by several authors. Ugurlu and Salman achieved over 96\% efficiency for phosphorous removal in batch and continuous conditions. Aksu and Yener compared sorption capacity of FA and GAC towards o- and p-chlorophenols, 
concluding that the alternative sorbents may constitute an interesting alternative, once the difference of sorption capacity (for GAC, 380 and $422 \mathrm{mg} / \mathrm{g}$, and for FA, 98.7 and $118.6 \mathrm{mg} / \mathrm{g}$, for o-chlorophenol and p-chlorophenol, respectively) is not significant when compared with the cost of the sorbent [4]. Atrazine (2-chloro-4-ethylamino-6-isopropylamino-1, 3, 5- triazine), a chlorinated triazine herbicide, is one of the most widely used pesticides in crops such as maize, sugarcane, citrus fruits, sorghum, and pineapple and has been sold under different commercial names such as Aatrex, Aatratol, Bicep, and Gasaprim. Due to its extensive use, long life, high geochemical mobility, and various toxic properties (LD50 1,869-3,080), it has environmental significance and needs remediation [5].

\section{Materials and Methods}

2.1. The Adsorbent. Coal FA (Kosovo A) was collected at the (Kosova A) PP, Bardhi i Madh $42^{\circ} 38^{\prime} 13^{\prime \prime}$ North, $21^{\circ} 1^{\prime}$ $34^{\prime \prime}$ East, altitude $554 \mathrm{~m}$, and the coal is mainly lignite.

In Figure 1(a), we have presented the map of the Republic of Kosovo, specifically, the coordinates of surface coal mining in the place called Bardhi i Madh. In Figure 1(b), we have the appearance of surface mining and in Figure 1(c), we have the appearance of the FA sampling site of the (Kosova A).

In the Table 1, we have presented the FA data of the (Kosova A) $P$, data which were obtained from the characterization of a sample by the X-ray diffraction method.

In Table 2, we have the data in \% of the components of the fly ash of the coal power plant Kosova A, where it is seen that the oxygen element dominates followed by $\mathrm{Ca}, \mathrm{Si}, \mathrm{C}$, and $\mathrm{Al}$. These data are also confirmed by spectrum 1 in Figure 2.

HF images of the power plant (Kosovo A) analyzed by using an scanning electron microscope (SEM) with resolution: $100 \mu \mathrm{m} ; 2 \times 20 \mu \mathrm{m}$ and $5 \mu \mathrm{m}$.

Figure 3 shows the SEM images of the fly ash samples of the Kosova A power plant, where it is seen that the particles have a spherical shape with a contact surface considered, and for this, the HF of the Kosova A power plant can be considered as a good adsorbent of pesticides.

\subsubsection{Factors Affecting FA Adsorption Performance.} Factors affecting adsorption performance are the effect of contact time and initial concentration of pollutants [2].

Table 3 shows the adsorption capacity of HF of coal in relation to organic compounds in general and to atrazine and benalaxyl in particular. The tabular data also include the values of the adsorbed amounts of these compounds which were obtained in this study.

\subsection{Benalaxyl and Atrazine}

2.2.1. Benalaxyl. Benalaxyl is a broad-spectrum phenylamide fungicide. The common name is benalaxyl, while the IUPAC name is methyl N-phenylacetyl-N-2, 6-xylyl-DLalaninate. The molecular formula of benalaxyl is $\mathrm{C}_{20} \mathrm{H}_{23} \mathrm{NO}_{3}$ with a molecular mass of $325.41 \mathrm{~g} \mathrm{~mol}^{-1}$ and has the following structure: https://pubchem.ncbi.nlm.nih.gov.
2.2.2. Atrazin. Atrazine is a broad-spectrum herbicide. The common name is atrazine, while the IUPAC name is 6chloro- $\mathrm{N}_{2}$-ethyl- $\mathrm{N}_{4}$-(propan-2-yl)-1，3，5-triazine-2,4-diamine. The molecular formula of atrazine is $\mathrm{C}_{8} \mathrm{H}_{14} \mathrm{ClN}_{5}$ with a molecular mass of $215.69 \mathrm{~mol}^{-1}$ and has the following structure: https://pubchem.ncbi.nlm.nih.gov.

Figure 4 shows the structures of pesticides: atrazine and benalaxyl which is the object of this research. Based on the steric effects (molecular packaging) of the structures of atrazine and Benalaxyl, it turns out that both pesticides show good adsorption affinity on the surface of the coal HF of the power plant Kosova A.

Pesticides are widely used in agriculture to increase crop yields and quality. Atrazine is one of the most widely used pesticides worldwide, being a long-term and large-area herbicide suitable for the removal of broadleaf weed species. Long-term atrazine residue accumulation in the soil accounts for $20 \%-70 \%$ of the applied dose during application and is one of the most commonly detected pesticides in soils and groundwater worldwide [14].

A number of studies explored modifying silicate minerals (clays and zeolites) as adsorbents for atrazine. examined removal of atrazine, lindane, and diazinone from water by organo-zeolites. However, the adsorption capacity for atrazine was the lowest $(2.0 \mathrm{mmol} / \mathrm{g})$ [15]. Atrazine can be mineralized by biological activity or immobilized by physicochemical processes, generating nonextractable residues; therefore, the conventional extraction methods for quantification of atrazine in soils may be inappropriate. As a result, the extraction method may be considered the most relevant step for quantification of atrazine and other triazines in soils; hence, it is of prime importance for the optimization of the extraction parameters. [16] Atrazine (ATZ) is one of the most heavily used types of herbicide that is currently widely applied in the agricultural operations of Western Australia. Therefore, the soil in this state is highly prone to exposure to atrazine due to agricultural operations such as storage, carrying, and application by pest control companies or users. [17].

2.2.3. Adsorption Study. We have studied the kinetics of adsorption of benalaxyl and atrazine with physical and chemical properties in Table 4, in coal FAPP (Kosovo A) in a ratio of $0.5 \mathrm{~g}: 10 \mathrm{ml}(0.5 \mathrm{~g}$ of coal FAPP (Kosovo A) with $10 \mathrm{ml}$ of distilled $\mathrm{H}_{2} \mathrm{O}$ ), where we have obtained aqueous solution of benalaxyl and atrazine $(10 \mathrm{~g} / \mathrm{ml})$ in time $10,20,30,60,120$, and $360 \mathrm{~min}$ and $24 \mathrm{~h}$. We held a blind test to observe any adsorption of benalaxyl and atrazine on the glass surface or their degradation during equilibrium. After reaching equilibrium, the flight coal FAPP (Kosovo A) was centrifuged at $1500 \mathrm{rpm}$ for $20 \mathrm{~min}$, and then we characterized benalaxyl and atrazine from the supernatant with GC/MS-QP2010S. The adsorbed amounts of benalaxyl and atrazine from coal FAPP (Kosovo A) was calculated from the changes of initial and final concentrations in the supernatant. We have observed that there is no adsorption process of benalaxyl and atrazine during equilibration time. To study the effect of the amount of coal FAPP (Kosovo A) on the adsorption of benalaxyl and 


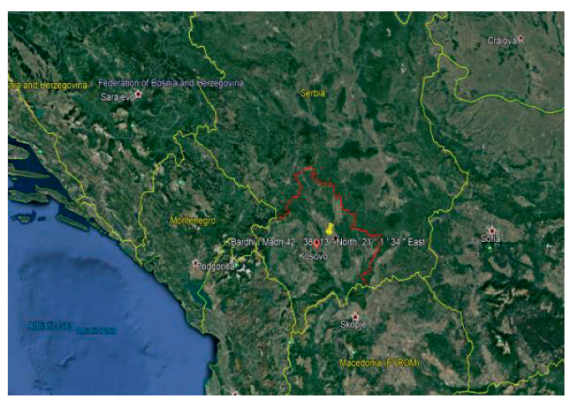

(a)

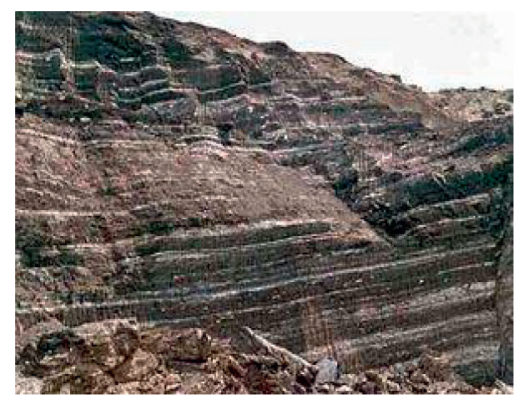

(b)

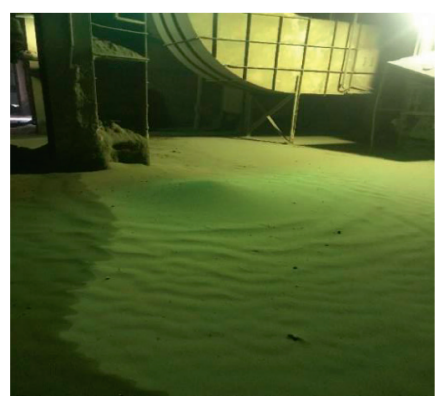

(c)

Figure 1: (a) Map of the Republic of Kosovo, (b) lignite layers, and (c) photo of coal FA (Kosovo A).

TABle 1: Data on coal FA (Kosovo A).

\begin{tabular}{|c|c|c|c|c|c|c|c|c|c|c|c|c|c|}
\hline $\mathrm{SiO}_{2}(\%)$ & $\mathrm{CaO}(\%)$ & $\mathrm{Fe}_{2} \mathrm{O}_{3}(\%)$ & $\mathrm{Al}_{2} \mathrm{O}_{3}(\%)$ & $\mathrm{MgO}(\%)$ & $\mathrm{P}_{2} \mathrm{O}_{5}(\%)$ & $\mathrm{TiO}_{2}(\%)$ & $\mathrm{Na}_{2} \mathrm{O}(\%)$ & $\mathrm{K}_{2} \mathrm{O}(\%)$ & $\mathrm{V}_{2} \mathrm{O}_{5}(\%)$ & $\mathrm{NiO}(\%)$ & $\mathrm{SO}_{3}(\%)$ & $\mathrm{MnO}(\%)$ & Others (\%) \\
\hline 25.5 & 3.6 & 7.5 & 9.4 & 5.5 & 0.3 & 0.3 & 1.1 & 0.6 & n.p & n.p & 9.0 & 0.2 & 2.0 \\
\hline
\end{tabular}

TABLe 2: Participation in \% of elements in the fly ash of the Kosovo A power plant.

\begin{tabular}{lcc}
\hline Element & Weight in $\%$ & Atom in \% \\
\hline $\mathrm{C}$ & 8.69 & 13.83 \\
$\mathrm{O}$ & 53.17 & 63.52 \\
$\mathrm{Na}$ & 1.47 & 1.22 \\
$\mathrm{Mg}$ & 2.41 & 1.89 \\
$\mathrm{Al}$ & 4.88 & 3.46 \\
$\mathrm{Si}$ & 11.65 & 7.93 \\
$\mathrm{Ca}$ & 15.47 & 7.37 \\
$\mathrm{Fe}$ & 2.26 & 0.77 \\
Total & 100.00 & \\
\hline
\end{tabular}

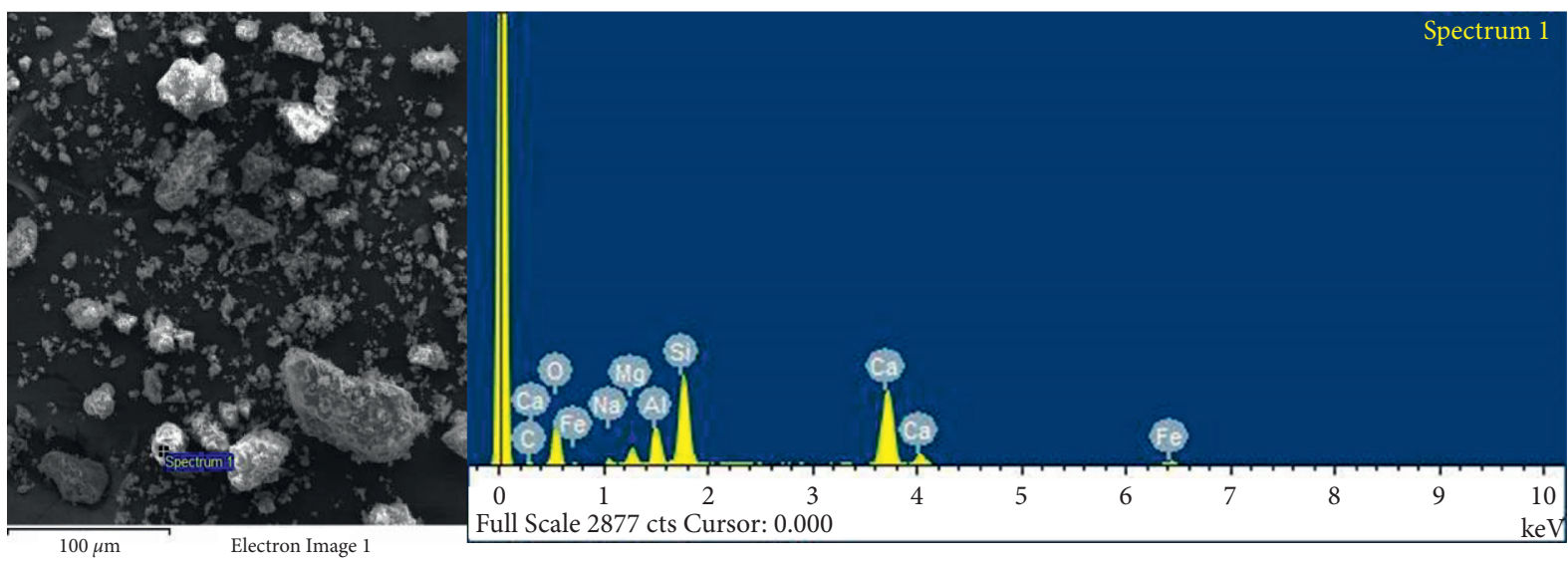

FIgURE 2: Semiquantitative analysis of FA power plant (Kosovo A) with SEM-EDX method.

atrazine, different amounts of coal FAPP (Kosovo A) (0.1-2 g) were equilibrated with $10 \mathrm{ml}$ of aqueous solution of benalaxyl and atrazine $(10 \mu \mathrm{g} / \mathrm{ml})$ for 2 hours. A blind test, without coal FAPP (Kosovo A), was held as a control. After equilibration, the coal FAPP (Kosovo A) suspension was centrifuged at $1500 \mathrm{rpm}$ for $20 \mathrm{~min}$, and the benalaxyl and atrazine residues were characterized in supernatant with GC/MS-QP2010S. The adsorbed amounts of benalaxyl and atrazine from the coal FAPP (Kosovo A) were calculated as mentioned above (from the extract). To obtain adsorption isotherms for benalaxyl and atrazine in coal FAPP (Kosovo A), we have $1.0 \mathrm{~g}$ for benalaxyl and $0.2 \mathrm{~g}$ for atrazine and $10 \mathrm{ml}$ of aqueous solution of benalaxyl and atrazine in a $50 \mathrm{ml}$ sample which were balanced for $2 \mathrm{~h}$ in room. A blind test, without coal FAPP (Kosovo A), was kept as a control. In these solutions, the concentrations of benalaxyl and atrazine varied between 2.5 and $500 \mu \mathrm{g} / \mathrm{ml}$ for benalaxylin and 2.0 and $10 \mu \mathrm{g} / \mathrm{ml}$ for atrazine, and each concentration was repeated three times. After equilibration, 


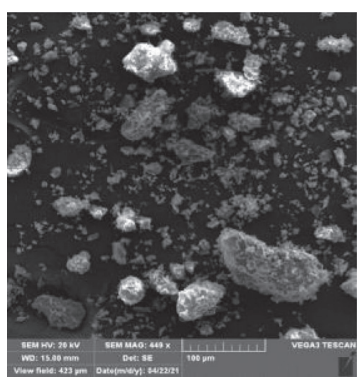

(a)

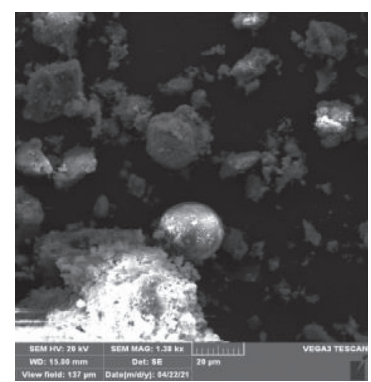

(b)

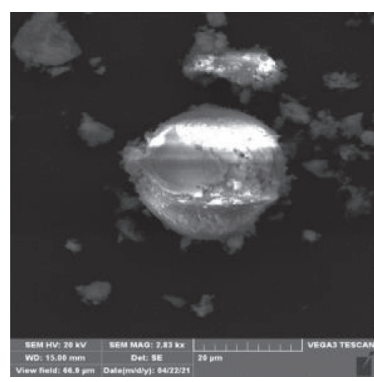

(c)

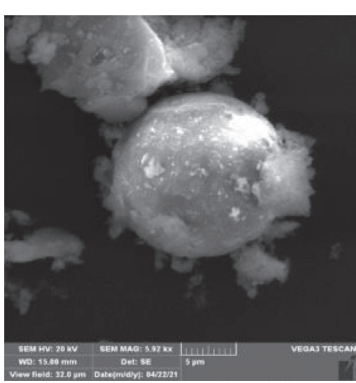

(d)

Figure 3: (a) Magnification $100 \mu \mathrm{m}$; (b) magnification $20 \mu \mathrm{m}$; (c) magnification $20 \mu \mathrm{m}$; and (d) magnification $5 \mu \mathrm{m}$.

TABLE 3: Adsorption capacity of coal FA.

\begin{tabular}{llcc}
\hline Organic pollutants & Fly ash type & Adsorption capacity & References \\
\hline Atrazine & Coal FA & $0.45 \mathrm{mg} / \mathrm{g}$ & This study \\
Benalaxyl & Coal FA & $0.46 \mathrm{mg} / \mathrm{g}$ & This study \\
Atrazine & Coal FA & $3.33 \mathrm{mg} / \mathrm{g}$ & This study \\
Benalaxyl & Coal FA & $3.48 \mathrm{mg} / \mathrm{g}$ & This study \\
Atrazine & Coal FA & $(1.2-11.6 \mu \mathrm{g} / \mathrm{g} / 50 \mu \mathrm{g} / \mathrm{g})$ & {$[5]$} \\
Cabofuran & Coal FA & $1.54-1.65 \mathrm{mg} / \mathrm{g}$ & {$[6]$} \\
Phenol & Coal FA & $67 \mathrm{mg} / \mathrm{g}$ & {$[7,8]$} \\
2,4-Dichlorophenol & Coal FA & $1.5-1.7 \mathrm{mg} / \mathrm{g}$ & {$[9]$} \\
2-Nitrophenol & Coal FA & $5.80-6.44 \mathrm{mg} / \mathrm{g}$ & {$[10]$} \\
3-Nitrophenol & Coal FA & $6.52-8.06 \mathrm{mg} / \mathrm{g}$ & {$[10]$} \\
$4-N i t r o p h e n o l$ & Coal FA & $7.80-9.68 \mathrm{mg} / \mathrm{g}$ & {$[10]$} \\
Cresol & Coal FA & $85.4-96.4 \mathrm{mg} / \mathrm{g}$ & {$[11]$} \\
Carbofuran & Coal FA & $1.54-1.65 \mathrm{mg} / \mathrm{g}$ & {$[6]$} \\
TCB & Coal FA & $0.35 \mathrm{mg} / \mathrm{g}$ & {$[12]$} \\
HeCB & Coal FA & $0.15 \mathrm{mg} / \mathrm{g}$ & {$[12]$} \\
Methylene blue & Coal FA & $14.4 \times 10^{-5} \mathrm{~mol} / \mathrm{g}$ & {$[13]$} \\
\hline
\end{tabular}<smiles>COC(=O)C(C)N(C(=O)Cc1ccccc1)c1c(C)cccc1C</smiles>

(a)<smiles>CCNc1nc(Cl)nc(NC(C)C)n1</smiles>

(b)

Figure 4: Structures of (a) benalaxyl and (b) atrazine.

the coal FAPP (Kosovo A) suspension was centrifuged at $1500 \mathrm{rpm}$ for $20 \mathrm{~min}$, and the benalaxyl and atrazine residues were characterized by the supernatant (extract) with GC/MSQP2010S. We have calculated the adsorbed amounts of benalaxyl and atrazine residues from coal FAPP (Kosovo A) as mentioned above. The desorption of benalaxyl and atrazine from coal FAPP (Kosovo A) has been studied in the same tests, where after adsorption, we have selected only two concentrations for desorption. After studying the adsorption, $5 \mathrm{ml}$ of the supernatant was removed and $5 \mathrm{ml}$ of fresh distilled water was added, and the suspension was balanced again for 2 hours. After reaching equilibrium, we suspended the suspension of the coal FAPP (Kosovo A) at $1500 \mathrm{rpm}$ for 20 minutes, decanted the supernatant, and characterized the residues of benalaxyl and atrazine as supernatant. Coal FAPP (Kosovo A) obtained after centrifugation has undergone two more desorption cycles. We performed a total of three desorptions for each sample and calculated the total amount desorbed by adding the amounts of benalaxyl and atrazine absorbed during each desorption. 
TABle 4: Physical properties of benalaxyl and atrazine.

\begin{tabular}{|c|c|c|c|c|c|c|c|}
\hline $\begin{array}{l}\text { Physical } \\
\text { properties }\end{array}$ & Melting point & $\begin{array}{l}\text { Relative } \\
\text { density }\end{array}$ & $\begin{array}{l}\text { Steam } \\
\text { pressure }\end{array}$ & $\begin{array}{l}\text { Description of } \\
\text { physical } \\
\text { condition and } \\
\text { color }\end{array}$ & $\begin{array}{c}\text { Solubility in organic } \\
\text { solvents }\end{array}$ & $\begin{array}{l}\text { Solubility of } \\
\text { pure substance } \\
\text { in } \mathrm{H}_{2} \mathrm{O}\end{array}$ & $\begin{array}{c}\text { Degree of } \\
\text { hydrolysis at } \\
\text { pH } 4,7 \text {, and } 9\end{array}$ \\
\hline \multicolumn{8}{|l|}{ Benalaxyl } \\
\hline Result & $76.8^{\circ} \mathrm{C}$ & $\begin{array}{c}1.181 \mathrm{~g} / \mathrm{mL} \text { at } \\
20^{\circ} \mathrm{C}\end{array}$ & $\begin{array}{c}\text { Extrapolating: } \\
5.72 \times 10-4 \mathrm{~Pa} \\
20^{\circ} \mathrm{C} \\
7.08 \times 10-4 \mathrm{~Pa} \\
28^{\circ} \mathrm{C} \\
19.6 \times 10-4 \mathrm{~Pa} \\
50^{\circ} \mathrm{C}\end{array}$ & $\begin{array}{c}\text { Pure active } \\
\text { substance: white } \\
\text { crystalline solid }\end{array}$ & $\begin{array}{c}\left(\mathrm{g} / \mathrm{kg} \text { at } 22^{\circ} \mathrm{C}\right) \\
\text { n-Heptane } 19.4 \text { xylene } \\
>250 \\
\text { Acetone }>250 \\
\text { Ethylacetate }>250 \\
1,2- \\
\text { Dichloroethane }>250 \\
\text { Methanol }>250\end{array}$ & $\begin{array}{c}\text { In distilled } \\
\text { water: } \\
\text { pH } 6.1 \\
28.6 \\
\mathrm{mg} / \mathrm{L} \text { at } 20^{\circ} \mathrm{C}\end{array}$ & $\begin{array}{c}\text { The } \\
\text { experimental } \\
\text { half-lives at } \mathrm{pH} \\
9 \text { were } 86 \text { days } \\
\left(25^{\circ} \mathrm{C}\right) \text { and } 157 \\
\text { days }\left(20^{\circ} \mathrm{C}\right)\end{array}$ \\
\hline Reference & $\begin{array}{l}\text { Costantini } \\
\text { G. et al. } 1995 . \\
\text { Report no: } \\
\text { 94/1087.C }\end{array}$ & $\begin{array}{c}\text { Costantini } \\
\text { G. etal. } 1995 . \\
\text { Report no: } 94 / \\
1087 . \mathrm{B}\end{array}$ & $\begin{array}{c}\text { Costantini } \\
\text { G. et al. } 1995 . \\
\text { Report no: } 94 / \\
\text { 1087.B }\end{array}$ & $\begin{array}{c}\text { Costantini } \\
\text { G. et al. } 1995 . \\
\text { Report no:94/ } \\
\text { 1087.B }\end{array}$ & $\begin{array}{c}\text { Costantini G. et al. } \\
1995 \\
\text { Report no: } 94 / 1087 . B\end{array}$ & $\begin{array}{l}\text { Costantini } \\
\text { G. et al. } 1995 . \\
\text { Report no: } 94 / \\
\text { 1087.B. }\end{array}$ & $\begin{array}{l}\text { Masoero M., } \\
\text { Crisippi T. } 1982\end{array}$ \\
\hline \multicolumn{8}{|l|}{ Atrazine } \\
\hline Result & $177.0^{\circ} \mathrm{C}$ & $1.2 \mathrm{~g} / \mathrm{cm}^{3}$ & $\begin{array}{c}40 \times 10^{-6} \mathrm{~Pa} \text { at } \\
20^{\circ} \mathrm{C}\end{array}$ & $\begin{array}{l}\text { Colorless or } \\
\text { white, odorless, } \\
\text { crystalline } \\
\text { powder }\end{array}$ & $\begin{array}{c}183 \mathrm{~g} / \mathrm{kg} \text { DMSO } \\
52 \mathrm{~g} / \mathrm{kg} \text { chloroform } \\
28 \mathrm{~g} / \mathrm{kg} \text { ethyl acetate } \\
18 \mathrm{~g} / \mathrm{kg} \text { methanol } \\
12 \mathrm{~g} / \mathrm{kg} \text { diethyl ether } \\
0.36 \mathrm{~g} / \mathrm{kg} \text { pentane }\end{array}$ & $\begin{array}{c}33.0 \mathrm{mg} / \mathrm{L} \text { at } \\
25^{\circ} \mathrm{C}\end{array}$ & $\begin{array}{c}\text { The half-life of } \\
\text { atrazine } \\
\text { hydrolysis in } \\
\text { distilled water } \\
\text { at } \mathrm{pH} 3, \mathrm{pH} 4.5 \\
\text { and pH } 8 \text { are: } \\
373 \text { days, } 522 \\
\text { days and } 657 \\
\text { days }\end{array}$ \\
\hline Reference & $\begin{array}{c}\text { Haynes, } \\
\text { W.M. (ed.). } \\
\text { CRC } \\
\text { Handbook of } \\
\text { Chemistry } \\
\text { and Physics. } \\
\text { 95th Edition. } \\
\text { CRC Press } \\
\text { LLC, Boca } \\
\text { Raton: FL } \\
\text { 2014-2015, p. } \\
\text { 3-30 }\end{array}$ & $\begin{array}{c}\text { LO } \\
\text { International } \\
\text { Chemical } \\
\text { Safety Cards } \\
\text { (ICSC) }\end{array}$ & $\begin{array}{c}\text { ILO } \\
\text { International } \\
\text { Chemical } \\
\text { Safety Cards } \\
\text { (ICSC) }\end{array}$ & $\begin{array}{l}\text { NIOSH. NIOSH } \\
\text { Pocket Guide to } \\
\text { Chemical } \\
\text { Hazards. } \\
\text { Department of } \\
\text { Health \& } \\
\text { Human } \\
\text { Services, } \\
\text { Centers for } \\
\text { Disease Control } \\
\text { \& Prevention. } \\
\text { National } \\
\text { Institute for } \\
\text { Occupational } \\
\text { Safety \& Health. } \\
\text { DHHS } \\
\text { (NIOSH) } \\
\text { publication no. } \\
\text { 2010-168 (2010). } \\
\text { Available from: } \\
\text { https://www. } \\
\text { cdc.gov/niosh/ } \\
\text { npg. }\end{array}$ & $\begin{array}{l}\text { Lide, D.R., G.W.A. } \\
\text { Milne (eds.). } \\
\text { Handbook of Data on } \\
\text { Organic Compounds. } \\
\text { Volume I. 3rd ed. CRC } \\
\text { press, inc. Boca Raton, } \\
\text { FL. 1994., p. V1: } 323\end{array}$ & $\begin{array}{c}\text { Yalkowsky, } \\
\text { S.H., he, Yan, } \\
\text { Jain, } \\
\text { P. Handbook of } \\
\text { Aqueous } \\
\text { Solubility Data } \\
\text { Second Edition. } \\
\text { CRC Press, Boca } \\
\text { Raton, FL 2010, } \\
\text { p. } 152\end{array}$ & $\begin{array}{l}\text { J Environ Sci } \\
\text { (China) 2001 } \\
\text { Jan; 13(1): } \\
\text { 99-103 }\end{array}$ \\
\hline
\end{tabular}

2.2.4. Extraction and Analysis. Benalaxyl and atrazine (Figure 2) residues in water samples were extracted by shaking the samples for $15 \mathrm{~min}(20 \mathrm{ml})$ with hexane + dichloromethane $1: 3(5 \mathrm{ml})$. The samples were then allowed to stand for $15 \mathrm{~min}$, and $1 \mathrm{~g}$ of sodium anhydride sulphate was added to each test to remove any traces of moisture from the samples [18]. Benalaxyl and atrazine residues in the extraction solvent (hexane+dichloromethane $1: 3$ ) were analyzed by GC/MS-QP2010S.

\section{Results and Discussion}

The results of the kinetics of benalaxyl and atrazine show that their adsorption in the coal FAPP (Kosovo A) is very fast, where $80 \%$ of the amounts of benalaxyl and atrazine are adsorbed in the coal FAPP (Kosovo A) in the first 10 minutes (Figure 5)

Freundlich model is applicable for multilayer adsorption, while Langmuir isotherm model is for monolayer adsorption [19]. With the gradual developments of diverse 


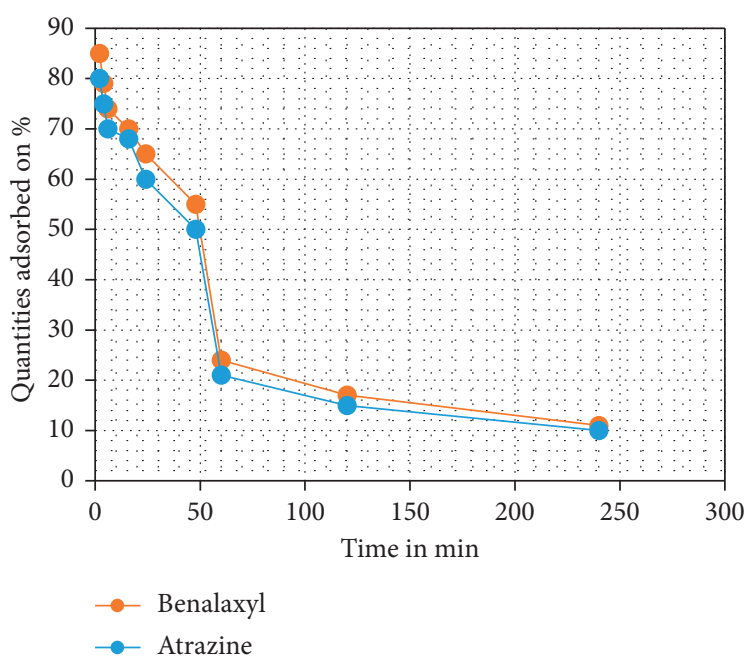

FIGURE 5: The \% adsorbed amount of benalaxyl and atrazine in coal FAPP (Kosovo A) over time.

adsorbent materials, the field of adsorption has become broader and specific in nature for particular pollutants including heavy metals, phenols, antibiotics, and pesticides [20]. We did not notice any significant change in the adsorption of benalaxyl and atrazine from the coal FAPP (Kosovo A) after $120 \mathrm{~min}$. For this reason, we have chosen the time $2 \mathrm{~h}$ as the equilibrium time. [21, 22]. We have also noticed that coal FAPP (Kosovo A) has the maximum adsorption capacity for benalaxylin, followed by atrazine. The effect of the amount of coal FAPP (Kosovo A) on the adsorption of atrazine and benalaxyl is shown in Figure 6 [23]. The results of this experiment show that the adsorbed amounts of benalaxyl and atrazine in coal FAPP (Kosovo A) increased with increasing amount of coal FAPP (Kosovo A). Atrazine adsorption was almost $100 \%$ when the amount of coal FAPP (Kosovo A) in solution $(10 \mathrm{ml})$ was $0.5 \mathrm{~g}$. The amount of FA required for $100 \%$ adsorption of benalaxyl was $0.45 \mathrm{~g}$ per $10 \mathrm{ml}$ of solution [2].

Adsorption data for benalaxyl and atrazine in coal FAPP (Kosovo A) were found from the Freundlich adsorption equation:

$$
\log C_{\mathrm{ads}}=\log K_{f}+\frac{1}{n} \log C_{e}
$$

where $C_{\text {ads }}$ is the adsorbed amount of pesticides in equilibrium $(\mu \mathrm{g} / \mathrm{g}), C$ is the concentration of pesticides in equilibrium $(\mu \mathrm{g} / \mathrm{ml})$, and $K_{f}$ and $1 / n$ are constant. Freundlich $K_{f}$ constant (intercept) represents the amount of pollutant adsorbed at an equilibrium concentration of $1 \mu \mathrm{g} / \mathrm{ml}$. The constant $1 / n$ (slope) is the measure of the adsorption intensity and reflects the degree to which the adsorption is a function of the pollutant concentration (Figure 7 and Table 5). [24] The values of the correlation coefficient for all cases were very high $\left(R^{2}>0.99\right)$, indicating that the Freundlich adsorption equation satisfactorily explained the adsorption results of benalaxyl and atrazine in coal FAPP (Kosovo A), and the results were significant at $99 \%$. Earlier, it was shown that compared to the Langmuir adsorption equation, the Freundlich adsorption equation better explained the atrazine adsorption results in flight ash [25].

The slope values $(1 / n)$ for benalaxyl and atrazine in the adsorption process from the slope values $(1 / n)$ for benalaxyl and atrazine in the adsorption process from the coal FAPP (Kosovo A) were <1 suggesting isotherms of nonlinear adsorption. Slope value $<1$ indicates $L$-type isotherms, which are characterized by decreased adsorption at higher aqueous concentrations of the compounds, i.e., adsorption of benalaxyl and atrazine in the coal FAPP (Kosovo A) was concentration dependent which was $<1$ suggesting isotherms of nonlinear adsorption. Slope value $<1$ indicates $L$-type isotherms, which are characterized by decreased adsorption at higher aqueous concentrations of the compounds, i.e., adsorption of benalaxyl and atrazine in the coal FAPP (Kosovo A) was concentration-dependent [21, 26]. This type of adsorption isotherms is observed when the molecules are in a flat position, not experiencing strong competition from the water molecule, which explains the high affinity to the adsorbent for the solution at low concentrations [27]. However, if the concentration increases, the adsorbent sites become restrictive; therefore, the adsorption decreases [28]. Earlier, Konstantinou and Albanis [21] and Majumdar and Singh [29] reported L-type adsorption isotherms for the adsorption of pesticides into fly ash and soil mixtures.

Comparison of $K_{f}$ values for benalaxyl and atrazine showed that the adsorption capacity of coal FAPP (Kosovo A) for benalaxyl is $0.47 \mathrm{mg} / \mathrm{g}$ followed by atrazine $(0.41 \mathrm{mg} /$ g). [30].

The order of adsorption of benalaxyl and atrazine in coal FAPP (Kosovo A) can be explained by their solubility in water because their adsorption is inversely proportional to their solubility in water $[31,32]$. The solutions of benalaxyl and atrazine in water are $28.6 \mathrm{mg} / \mathrm{L}$ at $20^{\circ} \mathrm{C}$ and $33.0 \mathrm{mg} / \mathrm{L}$ at $25^{\circ} \mathrm{C}$. Thus, benalaxyl, which has the lowest solubility in water, is more adsorbed to the coal FAPP (Kosovo A) [33].

Furthermore, the adsorption data were analyzed with the Langmuir equation: 


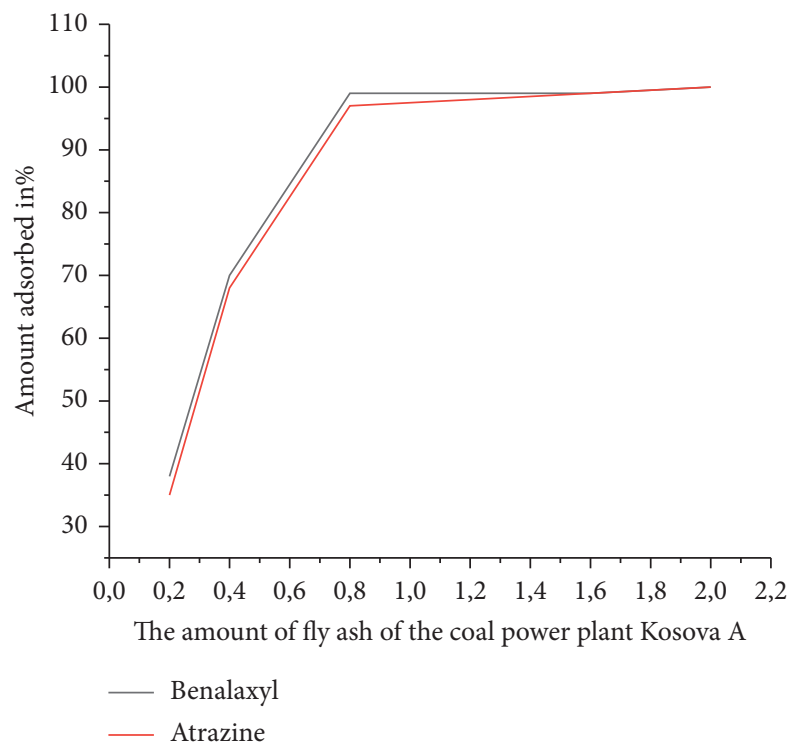

Figure 6: Amount of adsorbed \% of benalaxyl and atrazine in coal FAPP (Kosovo A) depending on the amount of coal FAPP (Kosovo A).

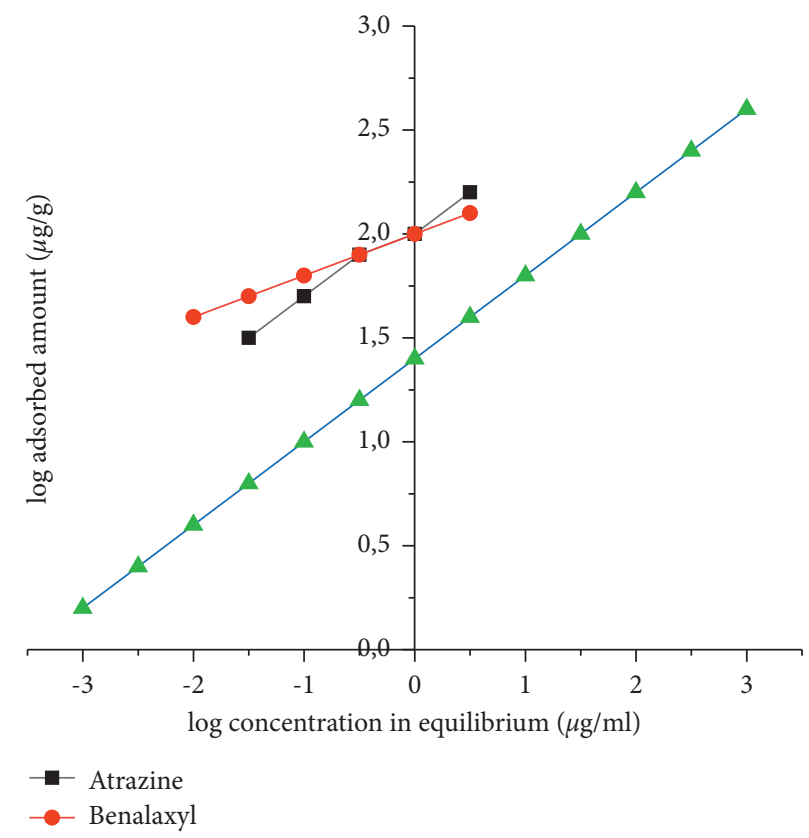

FIgURE 7: Freundlich adsorption isotherm for benalaxyl and atrazine in coal FAPP (Kosovo A).

$$
\frac{1}{C_{\mathrm{ads}}}=\frac{1}{q_{m}}+\frac{1}{q_{m}} b C_{e}
$$

where $q_{m}$ is the Langmuir constant which represents the maximum capacity of a layer and $b$ is the Langmuir constant associated with the adsorption energy [34]. The ratio between $1 / C_{\mathrm{ads}}$ and $1 / C_{e}$ for pesticide adsorption is shown in Figure 8 . The values $q_{m}$ and $b$ are estimated from the curve and slope and are given in Table 5 . We have noticed that the monolayer capacity $\left(q_{m}\right)$ of coal FAPP (Kosovo A) for pesticides $(\mu \mathrm{g} / \mathrm{g})$ was increasing in the order: atrazine $<$ benalaxyl, showing that coal FAPP (Kosovo A) has a maximum capacity to adsorb benalaxyl $(3.48 \mathrm{mg} / \mathrm{g})$ and atrazine $(3.33 \mathrm{mg} / \mathrm{g})$ [24].

This is similar to the results for the adsorption of benalaxyl and atrazine found from the Freundlich adsorption isotherm; however, the values found for the adsorption capacity of benalaxyl and atrazine using the Langmuir equation are almost 7 times higher than the values found using the equation Friendly [32]. Furthermore, parameter $b$, which is constant for the adsorption process and reflects the affinity of the adsorbent for pesticides, showed that the coal FAPP (Kosovo A) has maximum affinity for benalaxyl and atrazine [35]. 
TABLE 5: Adsorption parameters for adsorption of benalaxyl and atrazine in coal FAPP (Kosovo A).

\begin{tabular}{lcccccc}
\hline \multirow{2}{*}{ Pesticides } & \multicolumn{3}{c}{ Freundlich constants } & \multicolumn{3}{c}{ Langmuir constants } \\
& $K_{f}$ & $1 / n$ & $R^{2}$ & $q_{m}$ & $R^{2}$ \\
\hline Benalaxyl & 394.2 & 0.42 & 0,99 & 3489.6 & 388.9 & 0.95 \\
Atrazine & 379.4 & 0.38 & 0.99 & 3333.3 & 370.4 \\
\hline
\end{tabular}

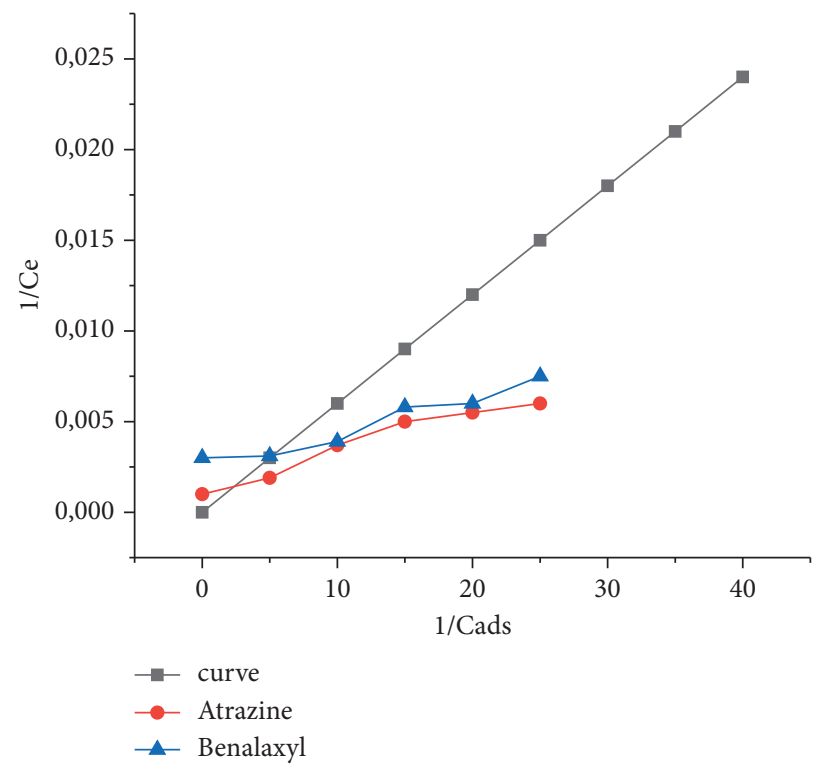

FIGURE 8: Langmuir adsorption isotherm for benalaxyl and atrazine in coal FAPP (Kosovo A).

TABle 6: Amount of benalaxyl and atrazine desorbed by coal FAPP (Kosovo A).

\begin{tabular}{|c|c|c|c|c|c|c|}
\hline \multirow{2}{*}{ Concentration $(\mu \mathrm{g} / \mathrm{ml})$} & \multirow{2}{*}{ The amount adsorbed } & \multicolumn{4}{|c|}{ Amount desorbed $(\mu \mathrm{g} / \mathrm{g})$} & \multirow{2}{*}{ Desorption in $\%$} \\
\hline & & I & II & III & Total & \\
\hline $\begin{array}{l}\text { Benalaxyl } \\
10 \mu \mathrm{g} / \mathrm{ml}\end{array}$ & 460 & 36.1 & 6.4 & 4,3 & 46.8 & 10.17 \\
\hline $\begin{array}{l}\text { Atrazine } \\
10 \mu \mathrm{g} / \mathrm{ml}\end{array}$ & 450 & 32.5 & 4.9 & 3.0 & 40.4 & 8.9 \\
\hline
\end{tabular}

This finding is consistent with the previous results whose results showed that the coal FAPP (Kosovo A) has a high affinity for both benalaxyl and atrazine [29].

Also, the value of the recovery coefficient $\left(R^{2}\right)$ for the adsorption of benalaxyl and atrazine using the Langmuir isotherm is 0.95 , which is lower than the corresponding values obtained using the Freundlich equation [36, 37]. Furthermore, the results of the second experiment showed that the coal FAPP (Kosovo A) has a maximum holding capacity for benalaxyl followed by atrazine. Therefore, based on the above data, it can be seen that Freundlich isotherm best explains the adsorption results of benalaxyl and atrazine coal FAPP (Kosovo A) because the value of the recovery coefficient $\left(R^{2}\right)$ for adsorption was very significant (level 99\%) $[1,38]$.

Comparing the efficiency of pesticide removal from water with adsorbent (coal FAPP (Kosovo A)) with other low cost adsorbents used by previous researchers categorizes it among the five efficient and low cost adsorbents [39], i.e., charcoal, rubber granules, bottom ash, macrofungus Sajor
Caju, and Florida to remove atrazine from drinking water [40, 41]. Charcoal shows the best adsorption capacity of atrazine with $Q_{\max } 0.80 \mathrm{mg} / \mathrm{g}$ followed by rubber granules with $0.47 \mathrm{mg} / \mathrm{g}$, and then the maximum capacity of coal FAPP (Kosovo A) to adsorb benalaxyl and atrazine was found to be 0.46 and $0.45 \mathrm{mg} / \mathrm{g}$, according to the Freundlich equation $[24,42]$. Thus, the result of our study suggests that coal FAPP (Kosovo A) has a good capacity to remove pesticides from aqueous solution and at low concentrations of pesticides $(<10 \mu \mathrm{g} / \mathrm{ml})$ can remove more than $99 \%$ of them $[35,36]$.

Results in Table 6 indicate that desorption of the sorbed compounds from fly ash of the coal of power plant (Kosovo A) was concentration dependent. Lesser amounts of herbicides were desorbed from the coal FAPP (Kosovo A) when sorption was carried out at low concentrations. Only $10.7 \%$ of sorbed benalaxyl was released after 3 repeated desorptions from coal FAPP (Kosovo A) when sorption was carried out at $10 \mu \mathrm{g} / \mathrm{ml}$ concentration. Desorption of atrazine was studied also at $10 \mu \mathrm{g} / \mathrm{ml}$ concentration, and during 3 
successive desorptions, nearly $8.9 \%$ of the sorbed atrazine was desorbed. These results suggest that if we compare desorption of benalaxyl and atrazine from coal FAPP (Kosovo A) at $10 \mu \mathrm{g} / \mathrm{ml}$ concentration, benalaxyl is the maximum desorbed.

\section{Conclusion}

In more analyzes performed, we were convinced that the internal standard should be added to the organic extract separated from the aqueous solution. The best extractor is the mixture: Heksan + dichloromethane in a ratio of $3: 1$ by volume, the extraction is done with the minimum possible volume of solvent, so that the final volume is as small as possible and we have a concentration that is normally analyzed in the gas chromatograph. Studying the dependence of the adsorption of benalaxyl and atrazine from coal FAPP (Kosovo A) on aqueous solutions, from the time of contact coal FAPP (Kosovo A) + water, it is noticed that, from $120 \mathrm{~min}$ to $180 \mathrm{~min}$, there is no visible adsorption of benalaxyl and atrazine on coal FAPP (Kosovo A). Further studies were therefore extended at intervals from $10 \mathrm{~min}$ to $120 \mathrm{~min}$. To stabilize the analysis on the gas chromatograph, a series of determinations were performed with standard solutions of benalaxyl and atrazine (99\%) and the internal standard DBF (99.5\%) until the achievement of optimal operating parameters, obtaining clear chromatograms with the respective points visible and easily calculated. We did not notice any significant change in the adsorption of benalaxyl and atrazine from the coal FAPP (Kosovo A) after $120 \mathrm{~min}$. For this reason, we have chosen the time $2 \mathrm{~h}$ as the equilibrium time.

\section{Data Availability}

The reference data used to support the findings of this study are included in the article.

\section{Conflicts of Interest}

The authors declare that they have no conflicts of interest.

\section{References}

[1] M. Ahmaruzzaman, "Role of fly ash in the removal of organic pollutants from wastewater," Energy \& Fuels, vol. 23, no. 3, pp. 1494-1511, 2009.

[2] K. A. Adegoke, R. O. Oyewole, B. M. Lasisi, and O. S. Bello, "Abatement of organic pollutants using fly ash based adsorbents," Water Science and Technology, vol. 76, no. 10, pp. 2580-2592, 2017.

[3] J. Ge, S. Yoon, and N. Choi, "Application of fly ash as an adsorbent for removal of air and water pollutants," Applied Sciences, vol. 8, no. 7, p. 1116, 2018.

[4] B. N. Estevinho, I. Martins, N. Ratola, A. Alves, and L. Santos, "Removal of 2,4-dichlorophenol and pentachlorophenol from waters by sorption using coal fly ash from a portuguese thermal power plant," Journal of Hazardous Materials, vol. 143, no. 1-2, pp. 535-540, 2007.

[5] R. K. Sharma, A. Kumar, and P. E. Joseph, "Removal of atrazine from water by low cost adsorbents derived from agricultural and industrial wastes," Bulletin of Environmental Contamination and Toxicology, vol. 80, no. 5, pp. 461-464, 2008.

[6] K. Kumari, R. P. Singh, and S. K. Saxena, "Adsorption thermodynamics of carbofuran on fly ash," Colloids and Surfaces, vol. 33, pp. 55-61, 1988.

[7] J. M. Lasco, "Value added utilization of fly ash prospective and sustainable solutions," Adsorption Science \& Technology, vol. 13, pp. 527-536, 1996.

[8] A. Akgerman and M. Zardkoohi, "Adsorption of phenolic compounds on fly ash," Journal of Chemical \& Engineering Data, vol. 41, no. 2, pp. 185-187, 1996.

[9] P. Kao, J. H. Tzeng, and T. L. Huang, "Removal of chlorophenols from aqueous solution by fly ash," Journal of Hazardous Materials, vol. 76, no. 2-3, pp. 237-249, 2000.

[10] B. K. Singh and P. S. Nayak, "Sorption equilibrium studies of toxic nitro-substituted phenols on fly ash," Adsorption Science \& Technology, vol. 22, no. 4, pp. 295-309, 2004.

[11] B. Dutta, J. K. Basu, and S. DasGupta, "Removal of cresol from aqueous solution using fly ash as adsorbent: experiments and modeling," Separation Science and Technology, vol. 38, no. 6, pp. 1345-1360, 2003.

[12] H. Nollet, M. Roels, P. Lutgen, P. Van Der Meeren, and W. Verstraete, "Removal of PCBs from wastewater using fly ash," Chemosphere, vol. 53, no. 6, pp. 655-665, 2003.

[13] T. Viraraghavan and K. R. Ramakrishna, "Fly ash for colour removal from synthetic dye solutions," Water Quality Research Journal, vol. 34, no. 3, pp. 505-518, 1999.

[14] H. Yu, Y. Liu, X. Shu et al., "Equilibrium, kinetic and thermodynamic studies on the adsorption of atrazine in soils of the water fluctuation zone in the three-gorges reservoir," Environmental Sciences Europe, vol. 32, no. 1, 2020.

[15] D. Zadaka, S. Nir, A. Radian, and Y. G. Mishael, "Atrazine removal from water by polycation-clay composites: effect of dissolved organic matter and comparison to activated carbon," Water Research, vol. 43, no. 3, pp. 677-683, 2009.

[16] M. F. Amadori, G. A. Cordeiro, C. C. Rebouças, P. G. PeraltaZamora, M. T. Grassi, and G. Abate, "Extraction method for the determination of atrazine, deethylatrazine, and deisopropylatrazine in agricultural soil using factorial design," Journal of the Brazilian Chemical Society, vol. 24, no. 3, pp. 483-491, 2013.

[17] M. Keramatikerman, A. Chegenizadeh, H. Nikraz, and Y. Yilmaz, "Mechanical behaviour of atrazine-contaminated clay," Applied Sciences, vol. 10, no. 7, p. 2457, 2020.

[18] H. Barchanska, M. Sajdak, K. Szczypka, A. Swientek, M. Tworek, and M. Kurek, "Atrazine, triketone herbicides, and their degradation products in sediment, soil and surface water samples in Poland," Environmental Science and Pollution Research, vol. 24, no. 1, pp. 644-658, 2017.

[19] A. Kumar, G. Sharma, M. Naushad et al., "Sustainable nanohybrids of magnetic biochar supported g- $\mathrm{C}_{3} \mathrm{~N}_{4} / \mathrm{FeVO}_{4}$ for solar powered degradation of noxious pollutants-synergism of adsorption, photocatalysis \& photo-ozonation," Journal of Cleaner Production, vol. 165, pp. 431-451, 2017.

[20] M. Naushad, S. Vasudevan, G. Sharma, A. Kumar, and Z. A. ALOthman, "Adsorption kinetics, isotherms, and thermodynamic studies for $\mathrm{Hg}^{2+}$ adsorption from aqueous medium using alizarin red-S-loaded amberlite IRA-400 resin," Desalination and Water Treatment, vol. 57, no. 39, pp. 18551-18559, 2015.

[21] I. K. Konstantinou and T. A. Albanis, "Adsorption-desorption studies of selected herbicides in soil-fly ash mixtures," Journal of 
Agricultural and Food Chemistry, vol. 48, no. 10, pp. 4780-4790, 2000.

[22] T. Wang, S. Ai, Y. Zhou et al., "Adsorption of agricultural wastewater contaminated with antibiotics, pesticides and toxic metals by functionalized magnetic nanoparticles," Journal of Environmental Chemical Engineering, vol. 6, no. 5, pp. 6468-6478, 2018.

[23] T. A. Albanis, P. J. Pomonis, and A. T. Sdoukos, "The influence of fly ash on pesticide fate in the environment. ii. hydrolysis, degradation and adsorption of Atrazine in aqueous mixtures of soils with fly ash," Toxicological \& Environmental Chemistry, vol. 19, no. 3-4, pp. 171-177, 1989.

[24] N. Ayawei, A. N. Ebelegi, and D. Wankasi, "Modelling and interpretation of adsorption isotherms," Journal of Chemistry, vol. 2017, Article ID 3039817, 11 pages, 2017.

[25] J. B. Alam, A. K. Dikshit, and M. bandyopadhyay, "Efficacy of adsorbents for 2,4-d and atrazine removal from water environment," Global NEST Journal, vol. 2, no. 2, pp. 139-148, 2000.

[26] R. K. Ghosh and N. Singh, "Adsorption-desorption of metolachlor and atrazine in Indian soils: effect of fly ash amendment," Environmental Monitoring and Assessment, vol. 185, no. 2, pp. 1833-1845, 2013.

[27] Z. T. Ahmed, "The quantification of the fly ash adsorption capacity for the purpose of characterization and use in concrete," Dissertation, Michigan Technological University, Houghton, Michigan, 2012.

[28] N. A. Fathy, O. I. El-Shafey, and L. B. Khalil, "Effectiveness of alkali-acid treatment in enhancement the adsorption capacity for rice straw: the removal of methylene blue dye," ISRN Physical Chemistry, vol. 2013, Article ID 208087, 15 pages, 2013.

[29] K. Majumdar and N. Singh, "Effect of soil amendments on sorption and mobility of metribuzin in soils," Chemosphere, vol. 66, no. 4, pp. 630-637, 2007.

[30] M. Harja, G. Buema, N. Lupu, H. Chiriac, H. Herea, and D. D. Ciobanu, "Fly ash coated with magnetic materials: improved adsorbent for Cu (II) removal from wastewater," Materials, vol. 14, no. 1, p. 63, 2021.

[31] C. Jarusiripot, "Removal of reactive dye by adsorption over chemical pretreatment coal based bottom ash," Procedia Chemistry, vol. 9, pp. 121-130, 2014.

[32] A. Kirk, K. VanDer, Q. Dongmei, A. Aktham, and W. Dale Eric, "Modified langmuir-like model for modeling the adsorption from aqueous solutions by activated carbons," Langmuir, vol. 21, pp. 217-224, 2005.

[33] World Health Organization, Atrazine in Drinking-Water, Background Document for Development of WHO Guidelines for Drinking-Water Quality, World Health Organization, Geneva, Switzerland, 2003.

[34] W. Donovan, "Benalaxyl (155)," United States Environmental Protection Agency, Washington, DC, USA, 2009.

[35] S. Wang and $\mathrm{H}$. Wu, "Environmental-benign utilisation of fly ash as low-cost adsorbents," Journal of Hazardous Materials, vol. 136, no. 3, pp. 482-501, 2006.

[36] N. Singh, "Adsorption of herbicides on coal fly ash from aqueous solutions," Journal of Hazardous Materials, vol. 168, no. 1, pp. 233-237, 2009.

[37] S. M. Shaheen, P. S. Hooda, and C. D. Tsadilas, "Opportunities and challenges in the use of coal fly ash for soil improvementsa review," Journal of Environmental Management, vol. 145, pp. 249-267, 2014.

[38] T. Ahmad, M. Rafatullah, A. Ghazali, O. Sulaiman, R. Hashim, and A. Ahmad, "Removal of pesticides from water and wastewater by different adsorbents: a review," Journal of Environmental Science and Health, Part C, vol. 28, no. 4, pp. 231-271, 2010.

[39] H. Li, G. Huang, C. An, J. Hu, and S. Yang, "Removal of tannin from aqueous solution by adsorption onto treated coal fly ash: kinetic, equilibrium, and thermodynamic studies," Industrial \& Engineering Chemistry Research, vol. 52, no. 45, pp. 15923-15931, 2013.

[40] Method 523: determination of triazine pesticides and theirdegradates in drinking water by gas chromatography/ massspectrometry (GC/MS), 2011, No. 815-R-11-002.

[41] X. Chen, "Modeling of experimental adsorption isotherm data," Information, vol. 6, p. 1422, 2015.

[42] F. Mushtaq, M. Zahid, I. A. Bhatti, S. Nasir, and T. Hussain, "Possible applications of coal fly ash in wastewater treatment," Journal of Environmental Management, vol. 240, pp. 27-46, 2019. 